\section{Canadian forest burn as model}

\section{Washington}

US and Canadian scientists flew to northern Ontario last weekend to watch what happens when 6 square kilometres of dry forest is doused with a petroleum mixture and set alight. Their aim was to see whether measurements from such planned fires could help to decide how likely it is that a nuclear war would give rise to "nuclear winter" - a global lowering of temperature caused by soot in the atmosphere. But the fire has already caused some unplanned political fallout.

The forest, 25 kilometres north-west of Chapleau, was infested with spruce budworm and was due to have been burned anyway - the Ontario Ministry of Natural Resources organizes about 50 such "prescribed burns" every year. This one, according to Bob Thomas of the Aviation

\section{Aleksandrov still not found}

ThE fate of Dr Vladimir Aleksandrov, the Soviet expert on nuclear winter who disappeared from an international meeting in Spain last March (see Nature 4 July, p.3), continues to cause concern to his colleagues abroad. Requests for information to Soviet colleagues have evoked only noncommittal responses such as "It was a tragedy, but we do not have many details". Some Soviet scientists have stated that their government has made requests for information through "diplomatic and other channels", but without success. According to one source, the Soviet government has also asked the International Committee for the Red Cross (IRC) to trace Aleksandrov, but Pascal Gondrand, spokesman of the IRC information department in Geneva, has no knowledge of any such request.

Although it has still not proved possible to establish Aleksandrov's movements immediately before his disappearance, details of his family situation received in the past month suggest that it is extremely unlikely that he disappeared voluntarily. He was known to be seriously concerned about his wife's health, and had sought the help of a London specialist, to whom he had sent, through a colleague, the results of a liver biopsy on Mrs Aleksandrova, carried out in the Soviet Union. The specialist had replied that it was impossible to complete a diagnosis solely on the basis of the materials so far supplied. Aleksandrov, however, was due to take part in a meeting of the ENUWAR (Environmental Consequences of Nuclear War) study group at the University of Essex in June, and (until he vanished) it was understood that he would take advantage of the meeting in England to deliver further diagnostic material to the London consultant.

Vera Rich and Fire Management Center in Sault Ste Marie, was no different from any other, though it was one of the larger ones. The forest, which had been bulldozed flat, was ignited from several points by helicopters flying in spirals, drenching the wood with a thickened petroleum compound much like napalm. This ignition technique, developed only last year, means that a forest can be burned very quickly.

Mike Frankel of the US Defense Nuclear Agency said last week that the purpose of the visit was simply to see whether the fire would be a true mass fire of the sort produced by nuclear explosions, as distinct from one composed of moving fronts, like a natural forest fire. If the fire were sufficiently intense, the trip might lead to a formal collaboration with the Canadians, with detailed observations of future prescribed burns from aircraft.

Although burning wood produces much less sooty smoke than would a burning city, and is therefore less likely to have climatic effects, there is still much that can be learned from studying mass forest fires, according to Frankel: the relation between energy release rates and the height of the convective column, the fate of entrained water vapour and the optical properties of the smoke plume as it is dispersed are all effects that cannot be predicted with confidence by extrapolating from small fires.

Canada has no formal nuclear winter research programme, although a report earlier this year from the Canadian Royal Society recommended that Canada should contribute to studies of this phenomenon. The idea of studying prescribed burns arose out of conversations between Frankel, George Carrier of Harvard University, who chaired the US National Academy of Sciences study of nuclear winter, and Brian Stocks of the Canadian Forestry Service. The fire was also watched by university researchers and by representatives of Environment Canada and the Canadian Department of National Defence; from the United States came observers from the Defense Nuclear Agency, TRW Inc. and Los Alamos National Laboratory. Any future collaboration would involve, on the US side, the Defense Nuclear Agency, which is (together with Lawrence Livermore National Laboratory) the main agency studying nuclear winter; the total US nuclear winter budget is put at $\$ 5.5$ million.

Nuclear weapons are a politically touchy issue in Canada and politics might limit the extent of future work. Although last weekend's observation was originally to have been an informal affair, indignant local press coverage obliged the Canadian authorities to be seen to be in charge, which they did by placing a limit on the number of observers.
Tim Beardsley
Athletic doping

\section{Hungarian owns up}

A Hungarian pharmacologist, Dr Zoltan Torma, has admitted administering banned drugs and anabolic steroids to Hungarian athletes, the first time that such an admission has been made in the socialist bloc. Writing in the Budapest literary weekly, Elat es irodalom, Dr Torma, who is employed at the National Physical Education and Sports Centre in Budapest, justified his actions by claiming that, left to themselves, the athletes would endanger their health by taking arbitrary doses. A qualified practitioner, he said, can at least administer the minimum necessary.

Dr Torma's article has sparked off an extensive discussion in the media on doping. Hungary's National Sports Office has in recent years spent the equivalent of US $\$ 250,000$ on anti-doping measures, but there seems to be tacit acceptance among Hungarian athletes and sports coaches that, without doping, Hungarian athletes cannot hope to compete internationally against competitors who resort to unauthorized use of drugs.

Dr Torma's excuse is not new. It was offered, for example, some years ago in the United States, in defence of allegations of doping in the case of the San Diego Chargers. What is significant, however, is that even the chief doctor of the Sports Office, Dr Istvan Kojtar, openly admitted, in an article in the sporting daily Nepsport, that it is virtually impossible to stop an athlete taking drugs if he is really set on doing so, and that doctors who refuse their assistance know that athletes risk severe damage to their health by self-administration. $\mathrm{He}$ suggested, however, that there should be a greater "social investigation" into the use of drugs in sport that would place it within the context of other social problems such as "nonsporting" drug abuse.

Dr Torma clearly agrees. He called for a clean up of Hungarian domestic sport, in which officials, coaches and athletes would be obliged to take a clear-cut stance against doping and the misuse of anabolic steroids. This, if Hungarian athletes' suspicions of their international competitors are correct, could considerably weaken Hungary's chances in international competition for some years.

The answer, clearly, is better doping control at the international level. Dr Torma himself would like to see a situation in which the International Olympic Committee would have the right to enforce random doping tests on any of its members at any time, so that athletes could be checked during training, and not just, as at present, immediately before a competition. However, not all members of the committee support this idea.

Vera Rich 